\author{
Adam Bartczak
}

\title{
CEL I FUNKCJA RĘKOJMI W KANONICZNYM PRAWIE MALŻEŃSKIM
}

\begin{abstract}
Streszczenie. Rękojmia jest instytucją funkcjonującą w kanonicznym prawie małżeńskim. W nim nabrała charakterystycznego znaczenia. Bez wątpienia wpisuje się ona w te instytucje, których celem jest ochrona małżeństwa. W artykule została przeprowadzona analiza rękojmi pod kątem celu i funkcji, jakie ma spełniać w prawie małżeńskim. Zarówno cel, jak i funkcja nie sprowadza się do jednego zagadnienia. Różnorodność odniesień czyni rękojmię niezwykle ważną, zwłaszcza w perspektywie społeczeństwa wieloreligijnego.
\end{abstract}

Słowa kluczowe: małżeństwo, rękojmia, przeszkoda, religia, wyznanie.

Małżeństwo jako związek mężczyzny i kobiety, cieszący się jednością i nierozerwalnością, przez Chrystusa podniesiony między ochrzczonymi do rangi sakramentu, jest istotnie ważną rzeczywistością, przede wszystkim faktyczną, ale - co interesuje kanonistów - nade wszystko prawną. Małżeństwo rozpatrywane jest jako węzeł prawny, który uzewnętrznia się przez wyrażenie zgody w przewidzianej prawem formie. Mamy więc do czynienia z czynnością prawną, która jako taka ma wywołać określone skutki prawne. Doniosłość tego wydarzenia zarówno w wymiarze faktycznym, jak i prawnym nie pozostała bez wpływu na działalność prawodawcy. Tę wolę odnajdujemy w różnych postaciach ochrony małżeństwa, wyrażonej w prawie kanonicznym. Tworząca się wspólnota małżeńska zostaje wystawiona na działalnie wielu okoliczności, które mogą zagrażać jej jedności czy nierozerwalności. Kościół od zawsze chronił małżeństwo, stanowiące podstawową komórkę społeczną i miejsce przychodzenia na świat kolejnych pokoleń, którym ochrzczeni rodzice przekazują wiarę. To w rodzinie kształtuje się wzorce, moralność, poglądy czy wiarę dzieci. Ta specyfika miejsca i osób jest chroniona w prawie kanonicznym m.in. przez instytucję rękojmi. W niniejszym artykule zostanie omówiona problematyka funkcji i celów, jakie rękojmia pełni w kanonicznym prawie małżeńskim.

* Uniwersytet Łódzki, Wydział Prawa i Administracji, Katedra Teorii i Filozofii Prawa, abartczak@wpia.uni.lodz.pl. 


\section{POJĘCIE RĘKOJMI}

W kanonicznym prawie małżeńskim nie spotykamy się literalnie z pojęciem rękojmi. Jest to nazwa, która funkcjonuje w doktrynie. Odnosi się ją w zasadzie do dwóch przepisów. W pierwszym przypadku pojęcie rękojmi pojawia się w kontekście przeszkody różnej religii (kan. $1086 \mathrm{KPK}$ ), w drugim zaś mowa jest o zawarciu małżeństwa mieszanego (kan. 1125 KPK). Pierwszy z przywołanych kanonów nie przedkłada nawet próby określenia, czym jest rękojmia. Ma on bowiem charakter przepisu odsyłającego (kan. 1086 KPK). Prawodawca odsyła nas do treści kanonów 1125-1126 KPK, a więc do już wyżej przywołanego drugiego przypadku. Mowa w nim oczywiście o możliwości zawarcia małżeństwa mieszanego, a szczegółowo - o przesłankach wymaganych do wydania zezwolenia przez kompetentną władzę (kan. 1124 KPK). A zatem zgodnie z kan. 1125 KPK:

tego rodzaju zezwolenia może udzielić ordynariusz miejsca, jeśli istnieje słuszna i rozumna przyczyna, nie może go jednak udzielić bez spełnienia następujących warunków: $1^{\circ}$ strona katolicka winna oświadczyć, że jest gotowa odsunąć od siebie niebezpieczeństwo utraty wiary, jak również złożyć szczere przyrzeczenie, że uczyni wszystko, co w jej mocy, aby wszystkie dzieci zostały ochrzczone i wychowane w Kościele katolickim; $2^{\circ}$ druga strona winna być powiadomiona $\mathrm{w}$ odpowiednim czasie o składanych przyrzeczeniach strony katolickiej, tak aby rzeczywiście była świadoma treści przyrzeczenia i obowiązku strony katolickiej; $3^{\circ}$ obydwie strony powinny być pouczone o celach oraz istotnych przymiotach małżeństwa, których nie może wykluczać żadna ze stron.

Uzupełnieniem tego kanonu jest kan. 1126 KPK, w którym czytamy:

Konferencja Episkopatu powinna zarówno określić sposób składania tych oświadczeń i przyrzeczeń, które są zawsze wymagane, jak i ustalić, w jaki sposób ma to być stwierdzone w zakresie zewnętrznym oraz jak ma być o tym powiadomiona strona niekatolicka.

Dokonując wykładni tych przepisów, należy wyodrębnić kilka istotnych zwrotów pojawiających się w tekście. Otóż, moim zdaniem, istotne dla wyjaśnienia pojęcia rękojmi wydają się następujące słowa: oświadczenie (declaratio), przyrzecznie (promissio), obowiązek (obligatio). Warto zwrócić uwagę na ciąg logiczny tych słów. Najpierw dokonuje się oświadczenie, czyli wypowiedź będąca wyrazem czyichś przekonań, poglądów (Mały słownik... 1996, 585). Ta zaś nie jest zwykłą wypowiedzią, lecz ma charakter bezwzględnego zapewnienia wykonania czegoś (tamże, 754-755). I wreszcie przez tę wypowiedź podmiot zaciąga na siebie wypełnienie obowiązku, to jest konieczność zrobienia czegoś wynikającego z nakazu wewnętrznego (moralnego) lub prawnego (tamże, 525).

Bezsprzecznie słowo „rękojmia” jest ściśle związane z prawem. Wywołuje $\mathrm{u}$ adresata swoiste poczucie bezpieczeństwa. Bardzo dokładnej i wnikliwej analizy pojęcia „rękojmia” dokonał J. Bralczyk. Zwrócił on uwagę, że słowo „rękojmia" niesie ze sobą silne, głębokie skojarzenie z uczciwością, rzetelnością, przez umocowanie w dawnej kulturze - nie tylko i może nie przede wszystkim 
prawnej. Słyszymy tu tak często wykorzystywaną metaforycznie rękę, a niektórzy rozpoznają tu też rdzeń -im-/-ją-, obecny w wielu słowach, takich jak przyjaćl przyjmować, zająć/zajmować i im podobnych, w tym również jać i imać, choć te są używane już rzadko i tylko w utartych połączeniach frazeologicznych. To połączenie dwóch słów jest dość osobliwe i nie do końca wiemy, jak ta ręka ma coś imać. Ale czujemy, że jak coś mamy w ręku, to jest to pewne. To zabezpieczenie czyjegoś zobowiązania (Bralczyk 2014) ${ }^{1}$. I dalej J. Bralczyk konstatuje:

I etymologicznie, i znaczeniowo, i, choć w mniejszym stopniu, kształtem rękojmia łączy się dziś z poręczeniem i z poręką. Kiedy za coś ręczymy czy też zaręczamy, dajemy taką rękojmię. Nawet w zaręczynach możemy się takiej rękojmi dopatrzeć. Możemy czasem dać sobie rękę uciąć - za coś lub za kogoś. To 'poręczenie, zagwarantowanie', a także bardziej osobiste 'zapewnienie, przyrzeczenie’ (Bralczyk 2014).

Stąd w Słowniku języka polskiego znajdujemy określenie „rękojmia” rozumiane jako poręka, poręczenie, zagwarantowanie, przyrzeczenie czegoś (Słownik języka polskiego 2016b).

A zatem o pojęciu rękojmi w znaczeniu przedmiotowym należy powiedzieć tyle, że w kanonicznym prawie małżeńskim oznacza oświadczenie składane przez stronę katolicką w formie przyrzeczenia wypełnienia ciążącego obowiązku. Ten obowiązek ma charakter dwuwarstwowy (Dzierżon 2008, 315).

Ponadto termin ,rękojmia” można scharakteryzować, odnosząc się do znaczenia podmiotowego. I tak, w obecnie obowiązującym prawodawstwie rękojmia jest instytucją, której podlegają jedynie wierni Kościoła katolickiego (kan. 1125 KPK). Wszak prawodawca nie pozostawia złudzeń, przedkładając normę, w której stwierdza, że to strona katolicka winna oświadczyć i złożyć przyrzeczenie.

\section{CEL RĘKOJMI}

Przez cel rozumie się pewien postulowany stan rzeczy, który winien być osiągnięty dzięki podjęciu określonych czynności. Tym samym cel jawi się jako rzeczywistość planowana, zamierzona przez tego, kto podejmuje określone

\footnotetext{
${ }^{1}$ „Rękojmia jest w polszczyźnie od XIV wieku, w towarzystwie takich pokrewnych słów jak rękojemca i rękojemstwo - i w takich znaczeniach, jakie miały oba te słowa. Najpierw bowiem rękojmia to był ktoś, kto ręczył. Oczywiście miał rodzaj męski: ten rękojmia. Dziwny dopełniacz brzmiał rękojmiego, a w liczbie mnogiej mówiło się o tych ludziach rekojmiowie. Dodajmy, że w tym znaczeniu występowały także słowa rękojm i rękojmi. Rękojmia to był więc poręczyciel, któremu w niektórych słowiańskich językach odpowiadał wręcz porucznik. Naszemu porucznikowi przecież także poruczano, czyli »powierzano« komendę, dziś to skojarzenie z ręka przy słowie porucznik rzadko się chyba pojawia. Ale wróćmy do rękojmiego albo zgoła do rękojmi. W kolejnych wiekach, najpierw przy zachowaniu pierwotnego osobowego znaczenia, rękojmia zaczęto nazywać czynność, czyli rękojemstwo, wreszcie to, co miało dawać pewność, czyli to, co określamy słowami zapewnienie, a także gwarancja. Najbliżej dziś jest rękojmi do bardziej czasem poręcznego słowa poręczenie”.
} 
działania czy stanowi określone normy prawne. Celem jest to, co ma czemuś służyć (Słownik języka polskiego 2016a). Rękojmia staje się zatem w tym świetle jedynie środkiem do osiągnięcia innego, potencjalnie większego dobra.

Wydaje się słuszne wprowadzenie w tym względzie podziału na cel bliższy i dalszy. Celem bliższym, bezpośrednim złożenia rękojmi jest zawarcie małżeństwa zgodnie z prawem kanonicznym. Jak zostało już wcześniej nadmienione, prawodawca wskazuje na konieczność złożenia rękojmi w dwóch przypadkach: 1) istniejącej przeszkody różnej religii; 2) małżeństwa mieszanego.

W pierwszym przypadku mamy do czynienia ze złożeniem rękojmi w celu uzyskania dyspensy od przeszkody różnej religii. Jest to sytuacja bardzo złożona. Rękojmia staje się podstawowym ogniwem dalszego ciągu zdarzeń, albowiem w sytuacji zawarcia małżeństwa pomiędzy katolikiem i osobą nieochrzczoną lub wyznającą jakąkolwiek inną religię lub pozostającą areligijną Kościół stawia przeszkodę, której pominięcie czyni małżeństwo nieważnym. Do ważnego zawarcia małżeństwa potrzeba udzielenia dyspensy, która stanowi warunek sine qua non. Dyspensa, będąca aktem łaski, może być udzielona po spełnieniu określonych wymogów. I tu pojawia się, wśród kilku warunków, złożenie rękojmi przez stronę katolicką.

W drugim przypadku złożenie rękojmi wymagane jest do zupełnie innej czynności. W przypadku zawierania małżeństwa mieszanego ordynariusz wydaje jedynie zezwolenie na zawarcie takiego małżeństwa na podstawie złożonych rękojmi. To zezwolenie nie jest wymagane do ważności aktu, jak to miało miejsce przy udzielaniu dyspensy od przeszkody różnej religii.

Dokładne wytyczne w tym względzie dotyczące obydwu przypadków zostały przedstawione w „Instrukcji Episkopatu Polski w sprawie duszpasterstwa małżeństw o różnej przynależności kościelnej” z 14 marca 1987 r. (KKBiDS 2016). Zgodnie z art. 6 lit. c tejże instrukcji:

należy przyjąć od strony katolickiej złożone na piśmie w trzech egzemplarzach oświadczenie, że uczyni wszystko, aby odsunąć od siebie niebezpieczeństwo utraty wiary oraz szczere przyrzeczenie, że uczyni wszystko, co w jej mocy, aby wszystkie dzieci zostały chrzczone i wychowane w Kościele katolickim, następnie powiadomić drugą stronę o oświadczeniu i przyrzeczeniu złożonym przez stronę katolicką; potem pouczyć obie strony o celach i istotnych przymiotach małżeństwa.

Rękojmia staje się więc koniecznym środkiem do osiągnięcia celu bliższego, jakim jest zawarcie małżeństwa. I choć w dwóch analizowanych przypadkach mamy do czynienia z inną kategorią udzielanego przez ordynariusza reskryptu (do ważności) oraz zezwolenia (do godziwości), to wymóg formalny jest ten sam. Na gruncie prawa warte podkreślenia jest to, iż brak rękojmi jedynie w przypadku przeszkody różnej religii wpłynie na niewypełnienie warunków udzielenia dyspensy, a to będzie skutkowało oczywiście nieważnością małżeństwa. Wynika to bowiem z natury samej przeszkody. Choć pochodzi ona z prawa kościelnego, to pośrednio wiąże się z prawem Bożym związanym z obowiązkiem wyznawania 
wiary. Dlatego muszą zostać spełnione określone warunki do udzielenia dyspensy (Góralski 2006, 130). Jak czytamy w przywołanym art. 6 lit. c instrukcji:

gdyby strona katolicka nie chciała złożyć wymaganych oświadczeń i przyrzeczeń, sprawy należy zaniechać; w przypadku, gdy strona niekatolicka nie akceptuje oświadczenia i przyrzeczenia strony katolickiej, a wręcz stwierdza, że nie dopuści do ich realizacji, obydwie strony mają podjąć decyzję wspólną i dopiero wtedy, jeśli będzie potrzeba, duszpasterz zwróci się do ordynariusza.

Cel dalszy rękojmi nie może zostać sprowadzony do jakiejś jednej kwestii. Według mojej oceny jest kilka istotnych odniesień. Aby je przeanalizować, powrócę powtórnie do kan. $1125,1^{\circ} \mathrm{KPK}$. Strona katolicka winna oświadczyć, że jest gotowa odsunąć od siebie niebezpieczeństwo utraty wiary, jak również złożyć szczere przyrzeczenie, że uczyni wszystko, co w jej mocy, aby wszystkie dzieci zostały ochrzczone i wychowane w Kościele katolickim. Pierwsza część przedmiotowo odnosi się do zachowania wiary. Wśród podstawowych obowiązków wszystkich wiernych jest zachowanie wspólnoty z Kościołem (kan. 209 § 1 KPK). Obowiązek ten, jak pisze W. Góralski, wynika z natury Kościoła i obejmuje zarówno wewnętrzną, jak i zewnętrzną sferę działania (Góralski 1996, 16). W pełnej wspólnocie Kościoła katolickiego, jak dodaje prawodawca w kan. 205 KPK, pozostają tutaj na ziemi ci ochrzczeni, którzy w jego widzialnym organizmie łączą się z Chrystusem więzami wyznawania wiary, sakramentów i zwierzchnictwa kościelnego. Zwłaszcza istotny w omawianej tematyce staje się aspekt wyznawania wiary. Bez przyjęcia aktem wiary wszystkich prawd, które są zawarte w depozycie wiary i są przekazywane przez nieomylne Magisterium Kościoła jako objawione, osoba sama stawia się poza pełną wspólnotą z Kościołem (Krukowski 2005, 18). Obowiązek zachowania wiary wynika z (jest konsekwencją) przyjętego sakramentu chrztu. Przez tę bramę człowiek wstępuje do Kościoła. Człowiek przez chrzest staje się osobą, w rozumieniu prawnym, w Kościele. Nabywa prawa, ale i zaciąga określone zobowiązania. W kan. 849 prawodawca stwierdza bowiem, że „chrzest, brama sakramentów, konieczny do zbawienia [...] przez upodobnienie do Chrystusa niezniszczalnym charakterem włącza ludzi do Kościoła".

Druga część kan. 1125, $1^{\circ} \mathrm{KPK}$, odnosi się do innego ważnego obowiąz$\mathrm{ku}$, jaki spoczywa na wiernym. Wychowanie katolickie potomstwa wpisuje się w obowiązek ewangelizacji, ale też stanowi pierwsze prawo i najwyższy obowiązek rodziców (kan. 1136 KPK). W Deklaracji o wychowaniu chrześcijańskim Gravissimum educationis Soboru Watykańskiego II czytamy: „Ponieważ rodzice dali życie dzieciom, w najwyższym stopniu zobowiązani są do wychowania potomstwa i dlatego należy ich uważać za pierwszych i najlepszych wychowawców" (Sobór Watykański II 2002b, 319). Ten obowiązek jest podstawowy i niezbywalny (tamże). Potomstwo jest jednym z celów małżeństwa sakramentalnego. Wpisuje się ono naturalnie w relację mężczyzny i kobiety. Ze względu na swoje powołanie do życia w małżeństwie, tworzenia rodziny, troska o wychowanie staje się konkretnym działaniem, odpowiedzią na treść tego powołania (Jan Paweł II 
1997, 137-138)2. Prawodawca w kan. 1136 KPK podkreśla zarówno fizyczne, społeczne i kulturalne, jak i moralne oraz religijne wychowanie potomstwa. Tym samym wskazuje na najważniejsze sfery życia ludzkiego. Z jednej strony rodzice mają gwarantować rozwój fizyczny, a z drugiej - duchowy dzieci. To na nich spoczywa ukształtowanie młodego człowieka w sferze społecznej i kulturowej (Bartczak 2014, 124). Pozostałe podmioty, które również uczestniczą w procesie edukacji dzieci, działają jedynie w imieniu rodziców, na podstawie ich zgody, a w pewnej mierze nawet na ich zlecenie.

A zatem w analizowanym kontekście celem rękojmi jest zachowanie własnej wiary oraz przekazanie jej kolejnemu pokoleniu. Zagwarantowanie tego obowiązku poprzez złożenie oświadczenia i przyrzeczenia ma podkreślać jego wagę, a zarazem wskazuje na trudność w ewentualnym wypełnianiu go w sytuacji małżeństwa szeroko rozumianego jako mieszane. Celem dalszym staje się więc salus animarum. To właśnie zasada salus animarum suprema lex, określona w ostatnim kanonie Kodeksu prawa kanonicznego z 1983 r., wyznacza cel, do którego zmierza osoba w Kościele i - można powiedzieć - dzięki Kościołowi oraz jego prawom. Wszak sakrament małżeństwa, jak pisze papież Franciszek, jest darem dla uświęcenia i zbawienia małżonków, ponieważ poprzez sakramentalny znak ich wzajemna przynależność jest rzeczywistym obrazem samego stosunku Chrystusa do Kościoła (Franciszek 2016, 59).

\section{FUNKCJE RĘKOJMI}

Zadanie, które spełnia - albo ma spełnić - rękojmia jest jej funkcją. Wypełnienie zadania w perspektywie celów wzmacnia instytucję rękojmi, lecz nade wszystko umacnia pozycję małżeństwa, dla której przecież została utworzona. Przez funkcję można też rozumieć obiektywny skutek, rezultat istnienia instytucji rękojmi dla nupturientów, następnie małżonków czy wreszcie wspólnoty wiary - Kościoła. W tym znaczeniu można zatem podkreślić, że o ile ten skutek zaistniał, funkcja będzie pokrywać się z celem. Funkcje, jakie spełnia rękojmia, nie dają się zamknąć w jakimś jednym kryterium - zostaną one omówione poniżej.

${ }^{2}$ „Nie można zapominać, że poza tymi cechami, charakteryzującymi zadanie wychowawcze rodziców, najgłębszym i określającym je elementem jest miłość ojcowska i macierzyńska, która znajduje w dziele wychowawczym wypełnienie doskonałej służby życiu: miłość rodzicielska od początku staje się duszą, a przez to i normą, która inspiruje i nadaje kierunek całej konkretnej działalności wychowawczej, ubogacając ją tak cennymi owocami miłości, jak czułość, stałość, dobroć, usłużność, bezinteresowność i duch ofiary". 


\subsection{Funkcja stabilizacyjna - wspólnotowa}

Funkcja stabilizacyjna rękojmi wyraża się w relacji pomiędzy nią samą a rzeczywistością prawa kanonicznego, a szerzej - całej wspólnoty Kościoła. Instytucja rękojmi oddziałuje na kanoniczne prawo małżeńskie poprzez wprowadzanie ładu w cały system tej gałęzi prawa. Na uwagę zasługuje tu przede wszystkim odniesienie do roli i miejsca, jakie pełni samo małżeństwo jako instytucja prawna, ale nade wszystko jako trwałe przymierze oparte na bezwarunkowej miłości, wpisane w historię zbawienia (Chapman 2007, 30-33). Poprzez rękojmię prawodawca pragnie stabilizować, a tym samym umacniać rangę małżeństwa. Świadomość wyjątkowości charakteru małżeństwa podkreślana jest przez fakt istnienia rękojmi. I nieprzypadkowo pojawia się ona w kontekście wyjątkowym, gdy mamy do czynienia z zawarciem małżeństwa szeroko rozumianego jako mieszane - kiedy z różnych względów dosyć łatwo o próbę rozbicia czy rozpadu wspólnoty życia małżeńskiego osób na poziomie religijnym. Nierozerwalność małżeństwa, tak ważna, istotna i przede wszystkim będąca przymiotem małżeństwa kanonicznego, właśnie przez rękojmię jest chroniona. Rękojmia powoduje podkreślenie rangi małżeństwa, skutkując nierutynowym podejściem do jego zawarcia. Wyrabia postawę nupturientów, a w konsekwencji przyszłych małżonków. Wszak prawo istnieje dla chrześcijan, katolików, nie po to, żeby służyć potępianiu albo ograniczaniu życia. Przeciwnie - jest ono po to, aby życie człowieka stawało się bogatsze, a człowiek był, jak podkreśla $\mathrm{S}$. de Lestapis, bardziej prawdziwie i trwale szczęśliwy (de Lestapis 1979, 12).

\subsection{Funkcja ochronna}

Rękojmia w swoim podstawowym zadaniu, jakie ma do spełnienia, odnosi się do ochrony małżeństwa. Małżeństwo jako przymierze mężczyzny i kobiety jest związkiem z ustanowienia Bożego (Sobór Watykański II 2002d, 563). Jest ono wpisane w samą naturę mężczyzny i kobiety (Trybunał 2012)3. Małżeństwo staje się podstawową komórką społeczną, w której przychodzi na świat kolejne pokolenie, przekazuje się wiarę, postawy moralne, tradycję (Hałas 1997, 222)4.

${ }^{3}$ „Małżeństwo nie jest jednym z wielu związków między osobami, który można kształtować wedle różnorakich wzorców kulturowych. Mężczyzna i kobieta w samych sobie znajdują naturalną skłonność do połączenia się w małżeństwie. Małżeństwo jednak, jak precyzyjnie wyjaśnia św. Tomasz z Akwinu, jest naturalne nie dlatego, że »wynika w sposób konieczny z zasad naturalnych «, lecz jako rzeczywistość, »ku której natura skłania, ale która zostaje dopełniona przez wolną wolę«".

${ }^{4}$ „Małżeństwo jest podstawowym, uznanym faktem społecznym badanym przez socjologów, ponieważ stanowi ośrodek tworzenia się rodziny. $Z$ funkcjonalnego punktu widzenia rodzina jest podstawowym systemem społecznym, służącym zastępowaniu członków społeczeństwa nie tylko w biologicznym sensie reprodukcji, służy bowiem także reprodukcji kulturowej i społecznej - używając terminu Pierre'a Bourdieu. W rodzinie dokonuje się przekaz tradycji i na ogół także 
Nie jest to przypadkowe miejsce. Przez fakt zawarcia małżeństwa powstaje za zrządzeniem Boskim instytucja trwała, również wobec społeczeństwa (Sobór Watykański II 2002d, 563), dlatego małżeństwo zasługuje na niepodważalną ochronę. Wyraża się ona w różnych instytucjach kanonicznego prawa małżeńskiego. Konsekwentnie widoczne są one $\mathrm{w}$ innych działach prawa, przede wszystkim w prawie procesowym. Można śmiało powiedzieć, że rękojmia staje w pierwszym rzędzie obrony małżeństwa. I choć mógłby ktoś zauważyć, że jest ona wymagana jedynie co do godziwości samego małżeństwa w przypadku małżeństw mieszanych, to w przypadku udzielania dyspensy od przeszkody różnej religii stanowi bardzo ważne ogniwo, a w zasadzie jeden z jej kilku warunków.

Rękojmia ma chronić przyszłe małżeństwo przed rozpadem, którego źródłem mogą być konflikty natury religijnej, a dokładnie stosunek małżonków do religii i konsekwencji, jakie niesie ze sobą przynależność do określonej religii czy wyznania. Nie możemy powiedzieć, iż rękojmia chroni jedynie stronę katolicką. Przeciwnie, chroni ona samo małżeństwo, które z racji przynależności nupturientów do różnej religii lub wyznania narażone jest na różnego rodzaju trudności. W ten sposób podkreślona została ranga samego małżeństwa. Warto zwrócić uwagę, że w zakresie omawianego problemu w różnych religiach, w sytuacji zawarcia małżeństwa z osobą innej wiary, ochrona małżeństwa przybiera niejednokrotnie formy restrykcyjne (Dzierżon $\mathrm{i}$ in. 2014). Rękojmia chroni zatem wartość, jaką jest małżeństwo w Kościele katolickim. Ochrona, jaką daje instytucja o charakterze prawnym, podkreśla doniosłość małżeństwa. Jak zauważa się w doktrynie, negatywny stosunek lub brak chęci do pielęgnowania i ochrony swojej wiary staje się przyczynkiem braku możliwości wniesienia stosownej prośby o wymagane przez prawo zezwolenie na zawarcie małżeństwa (Abate 1985, 187; Dzierżon 2014, 46).

\subsection{Funkcja gwarancyjna}

Rękojmia pełni w kanonicznym porządku prawnym także funkcję gwarancyjną. Co gwarantuje rękojmia? Na pewno nie samo istnienie czy dobre funkcjonowanie małżeństwa. Rękojmia nie zagwarantuje braku trudności i konfliktów pomiędzy małżonkami. Rękojmia jest gwarancją dla samej osoby ją składającej oraz potomstwa, które przyjdzie na świat z tego małżeństwa. Nupturient katolik składa oświadczenie przed wspólnotą, że zrobi wszystko, aby nie stracić swojej wiary. Jest to w jakimś sensie wyznanie wiary, które przechodzi w świadectwo

dziedziczenie pozycji społecznej. Małżeństwo jest urządzeniem racjonalnym, ponieważ zakłada podział praw i obowiązków pomiędzy stronami porozumienia. Małżeństwo polega na społecznie uznanym przyjęciu przez mężczyznę i kobietę statusu męża i żony w obrębie systemu pokrewieństwa. Czy to definiowane z punktu widzenia praw przysługujących małżonkom, czy to z punktu widzenia prawowitości potomstwa [...] małżeństwo jest czynnikiem racjonalności i porządku w obrębie systemu społecznego. Wskazuje na to choćby logika w systemie pokrewieństwa”. 
wiary. Zobowiązanie do trwania w wierze przybiera charakter nakazu samego prawa Bożego, którego w żaden sposób nie można derogować (Krukowski 2011, 331). Wiara, choć jest możliwa tylko dzięki łasce Bożej i wewnętrznej pomocy Ducha Świętego, jest aktem autentycznie ludzkim (KKK 2002, 154). Jak naucza nas Katechizm Kościoła Katolickiego, wiara jest konieczna do zbawienia. A zatem jej podtrzymanie jest obowiązkiem każdego chrześcijanina. $Z$ tego względu rękojmia staje się istotnym elementem salus animarum.

Wreszcie rękojmia zobowiązuje do przekazania wiary dzieciom poprzez chrzest oraz stosowne wychowanie religijne. W tym sensie rękojmia gwarantuje dzieciom wiarę przekazaną w Kościele katolickim.

\subsection{Funkcja wychowawcza}

Wychowywać to znaczy kształtować opinię, budzić bezpieczeństwo, zapewniać ochronę. Rękojmia wpisuje się właśnie w tę funkcję wychowawczą. Kształtuje ona wiedzę i świadomość na temat małżeństwa. Sprawia, że osoby chcące zawrzeć małżeństwo kanoniczne mają szansę dostrzec, iż nie jest to tylko i wyłącznie kontrakt, ale rzeczywistość o wiele bardziej złożona. Małżeństwo, które cieszy się jednością i nierozerwalnością, jest zabezpieczane przez rękojmię. Ta zaś z czasem staje się wyznacznikiem kształtującym prawdziwe rozumienie małżeństwa. Jest to niezmiernie ważne, zwłaszcza w dzisiejszych czasach, w których nurty liberalne zdają się ingerować również w kwestie związane z małżeństwem. Łatwość zrywania tej wspólnoty obliguje do stosownego kształtowania świadomości małżeństwa, przede wszystkim w młodych osobach, przyszłych nupturientach.

Kiedy dwoje ludzi różnych religii lub wyznań staje przed faktem zawarcia małżeństwa kanonicznego, rękojmia odgrywa swoją rolę wychowawczą zarówno wobec katolika, jak i drugiej strony. Wobec katolika rękojmia przypomina oraz podkreśla istotę małżeństwa w perspektywie wiary. Druga strona, przez fakt poinformowania o złożonych rękojmiach przez stronę katolicką, również styka się z pojęciem i funkcjonowaniem małżeństwa katolickiego, a w dalszej perspektywie - z pojęciem wiary w Kościele katolickim. Papież Benedykt XVI podkreślał, że nie można utożsamiać przygotowania do małżeństwa z ideologicznym przekazem natury zewnętrznej małżeństwa. Co więcej, nie jest to także forma narzucania wzorca kulturowego przyszłym małżonkom. Przeciwnie - jest to czas, poprzez który narzeczonym pomaga się odkrywać prawdę o naturalnej skłonności oraz zdolności zaangażowania się mężczyzny i kobiety, które są wpisane w ich relacyjny byt (Benedictus XVI 2011, 110-111).

Niezwykle istotna w całym procesie uzyskiwania zezwolenia na zawarcie małżeństwa mieszanego lub dyspensy od przeszkody różnej religii staje się norma wyrażona w kan. $1125,3^{\circ} \mathrm{KPK}$ : „obydwie strony powinny być pouczone o celach oraz istotnych przymiotach małżeństwa, których nie może wykluczyć żadna ze stron". Postawa wykluczająca w świetle prawa prowadzi oczywiście do 
nieważności małżeństwa. Jak pisze U. Nowicka, w tej perspektywie szczególnej rangi nabiera kwestia nierozerwalności małżeństwa, tak odmiennie interpretowana w różnych religiach czy wyznaniach (Nowicka 2015, 89).

\subsection{Funkcja misyjna}

Zobowiązanie do oddalenia utraty wiary oraz ochrzczenia i wychowania dzieci w Kościele katolickim podejmowane przez stronę katolicką wpisuje się bez wątpienia w wymiar misyjny, ewangelizacyjny powołania każdego wierzącego.

Wszyscy bowiem chrześcijanie wszędzie, gdziekolwiek żyją, są zobowiązani przykładem życia i świadectwem słowa tak ukazywać nowego człowieka, którego [...], aby inni, widząc ich dobre uczynki, chwalili Ojca oraz by mogli pełniej zrozumieć prawdziwy sens życia ludzkiego i dostrzec powszechną więź wspólnoty ludzkiej (Sobór Watykański II 2002c, 444).

Świadectwo wiary rozlewa się na powstającą rodzinę. Katolik składający rękojmię staje się misjonarzem swojej rodziny. Stając w prawdzie i wobec niej, obowiązkiem katolika staje się żyć prawdą, świadczyć o niej, a następnie ją głosić (Mogavero 2004, 192). Należy pamiętać, że źródłem tego obowiązku jest chrzest - brama sakramentów, akt, dzięki któremu człowiek nabywa zdolności działania w Kościele (Gałkowski 2007, 374). W ten sposób sama instytucja rękojmi, o czym była mowa wcześniej, wpisuje się w naczelną zasadę kanoniczną salus animarum suprema lex. Należy jednak wyraźnie podkreślać konieczność poszanowania drugiej strony ze względu na wyznawaną wiarę czy przynależność do innego wyznania. Każda osoba ludzka ma prawo do wolności religijnej (Sobór Watykański II 2002a, 411). Ma to swoje odniesienie zwłaszcza wobec chrztu dziecka i wychowania w duchu religii katolickiej. Warto w tym miejscu przywołać „Dyrektorium w sprawie realizacji zasad i norm dotyczących ekumenizmu” Papieskiej Rady ds. Jedności Chrześcijan z 25 marca 1993 r., które również podkreśla z jednej strony prawo do wolności religijnej, a z drugiej - obowiązek dzielenia się wiarą:

W wypełnianiu obowiązku przekazywania wiary katolickiej swoim dzieciom rodzic katolicki uszanuje wolność religijną i sumienie drugiego rodzica oraz będzie się troszczył o jedność i trwałość małżeństwa i o zachowanie komunii rodzinnej. Jeżeli pomimo tych wszystkich wysiłków dzieci nie zostaną ochrzczone w Kościele katolickim, rodzic katolicki nie podpada pod cenzurę prawa kanonicznego. Niemniej spoczywający na nim obowiązek dzielenia ze swymi dziećmi wiary katolickiej bynajmniej nie ustaje. Obowiązek ten trwa nadal i może się przyczynić na przykład do tego, że odegra on czynną rolę w budowaniu chrześcijańskiej atmosfery ogniska domowego; niech więc czyni, co tylko możliwe, słowem i przykładem, aby wspierać innych członków rodziny w docenianiu specyficznych wartości tradycji katolickiej; niech podejmuje wszelkie możliwe środki, by mógł, dobrze obeznany z własną wiarą, być zdolny wykładać ją i rozmawiać o niej z innymi; niech się modli razem ze swoją rodziną o łaskę jedności chrześcijan, takiej jakiej pragnie Pan (Papieska Rada ds. Jedności Chrześcijan 1994, 3-93). 


\section{PODSUMOWANIE}

Konkludując, należy podkreślić raz jeszcze specyfikę instytucji rękojmi, charakterystycznej jedynie dla porządku kanonicznego. W obrębie prawa małżeńskiego, będącego jedną z gałęzi prawa kanoniczego, swoje zastosowanie znalazła instytucja mająca na celu ochronę małżeństwa. W tej perspektywie jawią się zarówno cele, jak i funkcje, jakie rękojmia ma do spełnienia w porządku prawnym. Łatwo zauważyć, że rękojmia nie służy tylko jednemu celowi, nie ma także jednej funkcji. Rękojmia to instytucja bardzo złożona i wielowymiarowa. Wpisuje się bez wątpienia w podstawowe cele Kościoła. To zagadnienie wydaje się nadal aktualne, tym bardziej że w świecie mamy do czynienia z ogromną migracją wiernych, którzy pragną budować szczęśliwe związki. W tak multikulturowym świecie jeszcze bardziej potrzeba pokoju i silnych rodzin dążących do Prawdy, niezależnie od religii czy wyznania. Najważniejsza w tym względzie wydaje się sama rodzina tworzona przez małżeństwo. Kościół katolicki nie stoi na stanowisku zakazującym małżeństw mieszanych. Przeciwnie, stara się uczulić nupturientów na powagę, ważność i istotę związku, jaki zawierają, to jest małżeństwo. Stąd funkcjonująca w porządku kanonicznym instytucja rękojmi. Wszak prawo jest narzędziem pokoju (Łuczak 2010).

\section{BIBLIOGRAFIA}

\section{Źródła}

Benedictus XVI. 2011. „Ad sodales Tribunalis Romanae Rotae”. Acta Apostolice Sedis 103: 108-113. Franciszek. 2016. Posynodalna adhortacja apostolska „Amoris laetitia”. O mitości w rodzinie. Kraków: Wydawnictwo M.

Jan Paweł II. 1997. „Adhortacja apostolska Familiaris consortio”. W Adhortacje apostolskie Ojca Świętego Jana Pawła II. Kraków: Znak.

Katechizm Kościoła Katolickiego (KKK). 2002. Poznań: Pallottinum.

Mały słownik języka polskiego. 1996. Red. E. Sobol. Warszawa: PWN.

Sobór Watykański II. 2002a. „Deklaracja o wolności religijnej Dignitatis humanae”. W Sobór Watykański II. Konstytucje, dekrety, deklaracje. 410-421. Poznań: Pallottinum.

Sobór Watykański II. 2002b. „Deklaracja o wychowaniu chrześcijańskim Gravissimum educationis”. W Sobór Watykański II. Konstytucje, dekrety, deklaracje. 314-324. Poznań: Pallottinum.

Sobór Watykański II. 2002c. „Dekret o misyjnej działalności Kościoła Ad gentes divinitus”. W Sobór Watykański II. Konstytucje, dekrety, deklaracje. 433-471. Poznań: Pallottinum.

Sobór Watykański II. 2002d. „Konstytucja duszpasterska o Kościele w świecie współczesnym Gaudium et spes". W Sobór Watykański II. Konstytucje, dekrety, deklaracje. 526-606. Poznań: Pallotinum.

\section{Literatura}

Abate, Antonio. 1985. Il matrimonio nella nuova legislazione canonica. Brescia: Paideia. Bartczak, Adam. 2014. „Officium et ius w kan. 1136 KPK”. Prawo Kanoniczne 57 (4): 111-125. Chapman, Gary. 2007. Matżeństwo - przymierze czy kontrakt? Tajemnica trwałego matżeństwa. Przekł. Zbigniew Kościuk. Warszawa: Oficyna Wydawnicza „Vocatio”. 
de Lestapis, Stanislas. 1979. Małżeństwo. Przekł. Otylia Szczerska. Warszawa: Instytut Wydawniczy „Pax”.

Dzierżon, Ginter. 2008. Ewolucja doktryny oraz dyscypliny dotyczacych przeszkody różności religii w kanonicznym porządku prawnym. Warszawa: Wydawnictwo Uniwersytetu Kardynała Stefana Wyszyńskiego.

Dzierżon, Ginter. 2014. „Przygotowanie do zawarcia małżeństwa katolika z protestantem”. Ius Matrimoniale 25 (1): 41-54.

Dzierżon, Ginter, Waldemar Przyklenk, Paweł Stasiuk, Kinga Szymańska, Aleksandra Czapnik. 2014. Matżeństwo w Kościele katolickim oraz w czterech religiach niechrześcijańskich (judaizm, islam, hinduizm, buddyzm). Kraków: HomoDei.

Gałkowski, Tomasz. 2007. Prawo - obowiązek. Pierwszeństwo i wspólzależność w porzadkach prawnych: kanonicznym i społeczności świeckiej. Warszawa: Wydawnictwo Uniwersytetu Kardynała Stefana Wyszyńskiego.

Góralski, Wojciech. 1996. Lud Boży. Kościelne prawo osobowe. Częstochowa: Biblioteka „Niedzieli".

Góralski, Wojciech. 2006. Kościelne prawo matżeńskie. Warszawa: Wydawnictwo Uniwersytetu Kardynała Stefana Wyszyńskiego.

Hałas, Elżbieta. 1997. „Małżeństwo a kulturowe modele miłości”. W Rodzina w zmieniającym się spoleczeństwie. Red. Piotr Kryczka. 221-230. Lublin: Wydawnictwo Katolickiego Uniwersytetu Lubelskiego.

Krukowski, Józef. 2005. „Komentarz do kan. 205”. W Komentarz do Kodeksu Prawa Kanonicznego. T. II.1. Red. Józef Krukowski. 18-19. Poznań: Pallottinum.

Krukowski, Józef. 2011. „Komentarz do kan. 1125”. W Komentarz do Kodeksu Prawa Kanonicznego. T. III.2. Red. Józef Krukowski. 331-332. Poznań: Pallottinum.

Łuczak, Marek. 2010. Prawo narzędziem pokoju. Z ks. prof. Remigiuszem Sobańskim rozmawia ks. Marek Łuczak. Katowice: Księgarnia św. Jacka.

Mogavero, Domenico. 2004. „La libertà fondamentale del fedele: salvezza, annuncio, sacramenti”. W I dirritti fondamentali del fedele. Aventi anni dalla promulgazione del Codice. 191-197. Città del Vaticano: Libreria Editrice Vaticana.

Nowicka, Urszula. 2015. „Małżeństwa mieszane wedle koncepcji Kościoła katolickiego, Kościoła prawosławnego oraz Kościoła ewangelicko-augsburskiego w Polsce”. Ius Matrimoniale 26 (2): $85-100$.

Papieska Rada ds. Jedności Chrześcijan. 1994. „Dyrektorium w sprawie realizacji zasad i norm dotyczących ekumenizmu z 25 marca 1993 r.”. Communio 2: 3-93.

\section{Strony internetowe}

Bralczyk, Jerzy. 2014. „Z notatnika Jerzego Bralczyka. Rękojmia”. Temidium 3 (78), http://www. temidium.pl/content/eboks/Temidium7898/html5/index.html [dostęp 15.02.2016].

Komisja Kultu Bożego i Dyscypliny Sakramentów (KKBiDS). 2016. Instrukcja Episkopatu Polski w sprawie duszpasterstwa matżeństw o różnej przynależności kościelnej (14 marca 1987 r.). http://www.kkbids.episkopat.pl/?id=235 [dostęp 3.03.2016].

Słownik języka polskiego. 2016a. Hasło: „Cel”. http://sjp.pwn.pl/cel.html [dostęp 2.03.2016].

Słownik języka polskiego. 2016b. Hasło: „Rękojmia”. http://sjp.pl/rękojmia [dostęp 15.02.2016].

Trybunał. 2012. Przemówienie Ojca Świętego Jana Pawła II do pracowników i adwokatów Trybunału Roty Rzymskiej (1 lutego 2001 r.). http://www.trybunal.mkw.pl/Przemowienia\%20papieskie_2001.htm [dostęp 15.11.2016]. 
Adam Bartczak

\title{
THE PURPOSE AND FUNCTION OF THE WARRANTY IN THE CANONICAL MATRIMONIAL LAW
}

\begin{abstract}
Warranty is an institution functioning in the canonical matrimonial law. In this matrimonial law warranty took a characteristic meaning. Its mission is to protect an institution of the marriage. In the article there is an analysis of warranty with respect to the purpose and function to be played in the matrimonial law. Both the purpose and the function cannot be reduced to a single issue. The variety of references makes this institution very important, especially in a view of the multi-religious society.
\end{abstract}

Keywords: matrimonial, warranty, impediments, religion, faith. 